\title{
Pengembangan Pembelajaran Berbasis Web dengan menggunakan Teori Belajar Generatif
}

\author{
Mafrur Udhif Nofaizzi ${ }^{1}$, Saida Ulfa ${ }^{1}$, Dedi Kuswandi ${ }^{1}$ \\ ${ }^{1}$ Teknologi Pembelajaran-Universitas Negeri Malang
}

\section{INFO ARTIKEL}

\section{Riwayat Artikel:}

Diterima: 26-02-2019

Disetujui: 20-04-2020

\section{Kata kunci:}

learning web; generative learning theory; web pembelajaran; teori belajar generatif

\author{
Alamat Korespondensi: \\ Mafrur Udhif Nofaizzi \\ Teknologi Pembelajaran \\ Universitas Negeri Malang \\ Jalan Semarang 5 Malang \\ E-mail: udhiftep@gmail.com
}

\begin{abstract}
This study aims to develop web-based learning using generative learning theory. The stages of this research and developing are conducting analysis, designing, developing, implementing, and evaluating. The results of the development consist of web learning that involves learning activities selecting, organizing, and integrating. Then as a reinforcer of generative activity assignments with learning principles by summarizing and learning by explaining. The results of the attractiveness test obtained an average score of $89.09 \%$ which means students are interested in web-based learning using generative learning theory.
\end{abstract}

ABSTRAK

\begin{abstract}
Abstrak: Penelitian ini bertujuan untuk mengembangkan pembelajaran berbasis web dengan menggunakan teori belajar generatif. Tahapan dalam penelitian dan pengembangan ini, yaitu melakukan analisis, perancangan, pengembangan, penerapan, dan evaluasi. Hasil pengembangan berupa web pembelajaran yang terdapat aktivitas belajar menyeleksi, mengorganiasi, dan mengintegrasi. Kemudian sebagai penguat aktivitas generatif diberikan penugasan dengan prinsip learning by summarising dan learning by explaining. Hasil uji kemenarikan diperoleh skor rata-rata sebesar $89,09 \%$ yang menunjukkan bahwa mahasiswa tertarik dengan pembelajaran berbasis web dengan menggunakan teori belajar generatif.
\end{abstract}

Karakteristik pebelajar yang dibutuhkan pada abad ke-21 adalah pebelajar yang mampu mengatasi berbagai persoalan kehidupan dengan ciri kemampuan pemecah masalah, kreatif, inovatif, dan tangguh. Kemampuan tersebut dapat diasah dengan model pembelajaran yang tidak hanya berorientasi pada kemampuan hafalan saja atau berpikir tingkat rendah, tetapi pembelajaran yang berorientasi pada proses berpikir tingkat tinggi. Kemampuan berpikir tingkat tinggi, seperti berpikir kritis dan analisis, pemecahan masalah, inisiatif, inovatif sangat dibutuhkan pada era sekarang (O’Neal, Gibson, \& Cotten, 2017). Didalam sudut pandang yang lain, terdapat tiga domain kemampuan yang dubutuhkan pada abad 21, yaitu kognitif, intrapersonal, dan interpersonal (Pellegrino \& Hilton, 2013). Kompetensi kognitif, meliputi kemampuan berpikir kritis, memcahkan masalah, dan mengingat. Kompetensi intrapersonal meliputi emosi, perasaan, dan kemauan untuk mencapai suatu tujuan. Kompetensi interpersonal termasuk kemampuan dalam menyampaikan pesan kepada orang lain, menafsirkan pesan orang lain, dan kemampuan beradaptasi dengan lingkungan baru. Kompetensi-kompetensi tersebut dibutuhkan untuk membekali pebelajar dalam menghadapi lingkungan yang dinamis.

Salah satu faktor yang dapat mendukung pemenuhan kebutuhan kemampuan pebelajar adalah menentukan model belajar yang tepat didalam proses pembelajaran. Pembelajaran dapat dirancang untuk menghasilkan iuaran sesuai dengan kebutuhan. Perancangan pembelajaran bertujuan untuk meningkatkan kinerja pebelajar dan untuk meningkatkan efisiensi dan efektivitas sebuah sistem pembelajaran (Rothwell, Benscoter, King, \& King, 2015). Sehingga menentukan model belajar yang tepat dapat meningkatkan kemampuan pebelajar sesuai dengan tujuan yang diharapkan.

Belajar dapat terjadi jika pebelajar membangun hubungan antara bahan-bahan belajar yang digunakan saat ini dengan pengetahuan sebelumnya (Mayer, 2010). Proses belajar yang terjadi didalam diri manusia merupakan integrasi pengetahuan yang ada didalam diri manusia dengan informasi yang ada di sekelilingnya. Belajar terjadi ketika pebelajar aktif secara fisik dan kognisi dalam mengelola dan menggabungkan informasi baru kedalam struktur pengetahuan yang ada (Wilhelm-Chapin \& Koszalka, 2016). Sejalan dengan model belajar generatif, proses belajar generatif melibatkan kemampuan kognitifnya untuk memproduksi sebuah pemahaman baru yang diyakini akan kebenarannya. Model belajar generatif memandang proses belajar lebih efektif jika mengoptimalkan peran kognitif didalamnya. Kemampuan berpikir manusia diasah untuk memenuhi kebutuhan dalam pemecahan masalah dikehdiupan sehari-hari. 
Model belajar generatif dirancang untuk mencapai kemampuan berpikir kritis, analitis, kreatif, innovatif, dan meningkatkan pemahaman pebelajar dalam belajar. Keterampilan yang dibutuhkan pada abad kedua puluh satu seperti kemampuan pemecahan masalah, kreatif, berpikir kritis, inovatif, mampu beradaptasi, kemampuan komunikasi yang kompleks, dan berargumen dengan analisa dan bukti yang kuat merupakan harapan dalam menerapkan model belajar generatif (Fiorella \& Mayer, 2015). Dengan melibatkan proses kognitif dalam setiap aktivitas belajar, menjadikan pebelajar aktif dalam membangun pengetahuan baru. Penekanan teori belajar generatif terletak pada generasi yang memiliki pemahaman konseptual baru, bukan hanya transformasi informasi (Grabowski, 2004). Terdapat empat kunci utama yang perlu dipertimbangkan dalam pembelajaran bermakna, yaitu generation, motivation, attention, and storage (Wittrock, 1974). Generation dimaknai sebagai usaha untuk meningkatkan keaktifan berpikir dalam mengelaborasi bagian-bagian informasi menjadi sebuah satu pemahaman yang utuh. Upaya meningkatkan keaktifan berpikir diperlukan usaha yang keras, sehingga perlu adanya motivasi baik dari dalam diri pebelajar maupun dari luar. Pebelajar bukanlah penerima informasi yang pasif, melainkan penerima informasi yang aktif, pebelajar membangun pengetahuan yang didapatkan di lingkungannya (Lee, Lim, \& Grabowski, 2008). Sementara itu, atensi dan penyimpanan informasi dalam kaitannya dalam proses belajar adalah upaya untuk meningkatkan konsentrasi pebelajar dapat menggunakan media yang ada. Jika ketiga unsur tersebut dapat dipenuhi maka pengetahuan dapat tersimpan ke dalam memori jangka panjang. Pengetahuan yang tersimpan kedalam memori jangka panjang mudah untuk digunakan dalam pemecahan permasalahan sesuai dengan kebutuhan. menyebutkan bahwa memori jangka panjang memiliki karakteristik penyimpanan dengan kekuatan tinggi serta mencakup pengetahuan yang dipelajari dengan baik (Kalyuga, 2009).

Perkembangan teknologi informasi dan komunikasi yang pesat, mendorong lahirnya inovasi dalam dunia pendidikan. salah satunya penerapan model belajar generatif yang dipadukan dengan teknologi internet. penerapan model belajar generatif dengan menggunakan lingkungan belajar online memiliki dampak positif bagi hasil belajar. Penerapan model belajar generatif pada diskusi online berdampak signifikan terhadap hasil belajar (Beth, Jordan, Schallert, Reed, \& Kim, 2015). Mahasiswa tidak hanya memiliki dampak terhadap aspek kognitif saja tetapi juga rasa tanggung jawab dan sosial. Hal ini menunjukkan bahwa model belajar generatif mampu mendorong pebelajar dalam meningkatkan baik kemampuan dirinya maupun kapabilitas dirinya. Sehingga dapat memberikan dampak yang positif terhadap proses pembelajaran.

Berdasarkan kondisi tersebut, perlu dikembangkan pembelajaran berbasis web menggunakan model belajar generatif pada. Pengembangan ini berangkat dari kebutuhan akan kemampuan pebelajar abad ke-21. Sehingga penerapan model belajar generatif dinilai mampu memenuhi kebutuhan pebelajar abad ke-21. Rumusan masalah penelitian ini adalah bagaimana cara mengembangkan pembelajaran berbasis web menggunakan model belajar generatif dan sejauah mana tingkat kemenarikan model belajar generatif pada pebelajar?. Oleh karena itu, penelitian ini bertujuan untuk mendeskripsikan produk pengembangan desain pembelajaran berbasis web menggunakan model belajar generatif dan mengetahui tingkat kemenarikan model belajar generatif pada mahasiswa.

\section{METODE}

Penelitian dan pengembangan ini mengadopsi model pengembangan desain pembelajaran berbasis Web (DavidsonShivers, Rasmussen, \& Lowenthal, 2018). Pengembangan tersebut diawali dengan analisis masalah dalam pembelajaran untuk didapat solusi dalam mengatasi permasalahan tersebut. Kemudian dilanjutkan dengan tahapan disain sekaligus perencanaan evaluasi. setelah desain pembelajaran sudah dibuat, langkah selanjutnya secara berurutan adalah melakukan pengembangan, implementasi, dan evaluasi formatif. Proses desain hingga formatif evaluasi dapat dilakukan secara berulang hingga diperoleh hasil yang valid. Setelah proses terakhir dilaksanakan, kemudian langkah terakhir adalah melakukan evaluasi sumatif secara menyeluruh. Tahapan-tahapan dalam penelitian dan pengembangan desain pembelajaran berbasis Web dapat diilustrasikan pada gambar 1 .

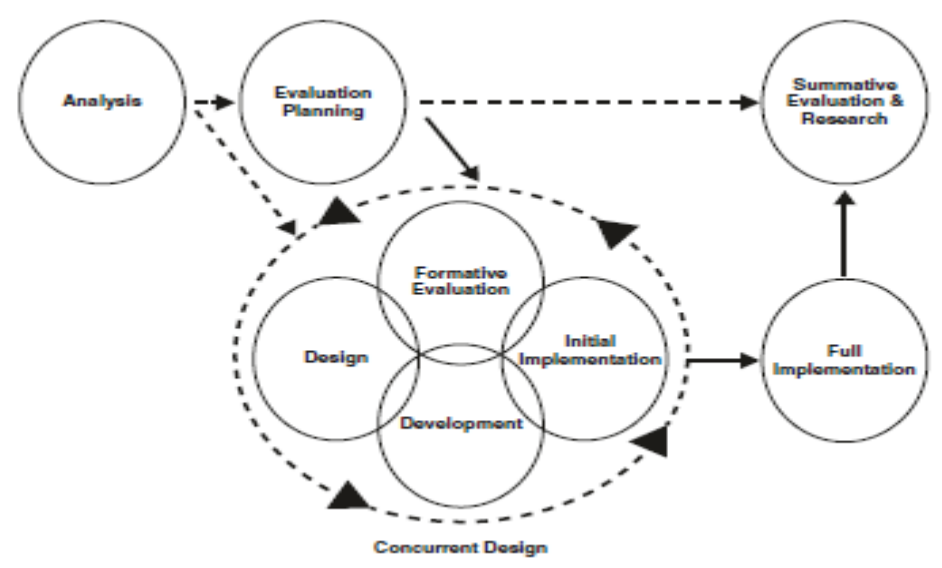

Gambar 1. Model Pengembangan Desain Pembelajaran Berbasis Web (Davidson-Shivers et al., 2018) 
Tahapan yang dilakukan pada penelitian ini mengadopsi model pengembangan desain pembelajaran berbasis Web. Setiap tahapan yang dilakukan akan berimplikasi pada tahapan berikutnya. Sehingga model dilakukan secara berurutan mulai tahap analisis hingga tahap evaluasi. Tahapan-tahapan tersebut memiliki tujuan masing-masing yang perlu dicapai. Sehingga setiap tahapan pengembangan yang dilakukan, mengarah pada penerapan model belajar generatif pada lingkungan belajar berbasis Web.

Tahapan awal adalah melakukan analisis mencakup tiga hal yaitu, konteks pembelajaran, pebelajar, dan tugas-tugas belajar. Tujuan yang akan dicapai pada tahap pertama ini adalah dapat mengetahui kebutuhan dan kondisi belajar pada matakuliah pengembangan bahan ajar pada jurusan Teknologi Pendidikan Universitas Negeri Malang, mengetahui karakjteristik dan minat belajar yang dimiliki oleh mahasiswa, mengetahui pengetahuan dan kemampuan awal termasuk pengalamanpengalaman yang dimiliki oleh mahasiswa, serta kemampuan dan pengetahuan awal. Mengetahui karakteristik pebelajar merupakan hal yang wajib diketahui untuk mengembangkan pembelajaran menggunakan model belajar generatif. Mengetahui kemampuan dan keterampilan awal digunakan untuk menyusun pembelajaran yang sesuai dengan kebutuhan pebelajar (Richey, Klein, \& Tracey, 2011).

Setelah melakukan analisis, kemudian dilanjutkan dengan proses perancangan dan pengembangan. Pada tahap ini, hal yang dilakukan adalah menentukan desain pembelajaran berbasis Web dengan mengintegrasikan strategi penyampaian, dan strategi manajemen dalam konteks pembelajaran menggunakan model belajar generatif. Tujuan yang akan dicapai pada tahap ini adalah memilih strategi yang tepat untuk membantu usaha mahasiswa dalam menghubungkan informasi-informasi yang ada untuk kebutuhan belajar. Memilih aktivitas-aktivitas yang tepat untuk menguatkan proses berpikirnya termasuk menentukan instruksi yang mengarah pada aktivitas generatif dan memilih strategi yang dapat mengaktifkan proses berpikir generatif mahasiswa. Pesan yang dirancang seharusnya mudah dipahami oleh pebelajar, sedangkan lingkungan belajar berbasis Web yang digunakan dalam proses pembelajaran dapat meningkatkan atensi pebelajar dalam proses pembelajaran. Rancangan pembelajaran yang telah ditetapkan kemudian dikembangkan menjadi sebuah produk yang siap untuk diterapkan.

Tahap terakhir yang dilakukan dalam proses pengembangan pembelajaran ini adalah melakukan evaluasi. Tahap ini dilakukan dengan tujuan untuk mengatahui seberapa efektif pembelajaran yang telah dikembangkan. Dalam konteks pembelajaran yang menggunakan model belajar generatif, terdapat dua hal yang perlu diperhatikan yaitu, (1) evaluasi yang dilakukan untuk mengetahui apakah pebelajar terlibat didalam aktivitas-aktivitas belajar generatif atau tidak (2) produk yang dihasilkan oleh pebelajar apakah terdapat kesenjangan dengan tujuan belajar yang telah ditentukan (Smith \& Ragan, 2005).

Subjek uji coba dalam penelitian dan pengembangan ini adalah mahasiswa program sarjana jurusan Teknologi Pendidikan Universitas Negeri Malang angkatan 2016 yang berjumlah 33 mahasiswa. Responden tersebut dipilih sesuai dengan kebutuhan dalam menerapkan pembelajaran menggunakan model belajar generatif. 33 mahasiswa tersebut dibagi kedalam dua kelompok dimana kelompok perorangan berjumlah tiga orang, sedangkan kelompok kecil berjumlah 30 orang. Jumlah tersebut ditentukan berdasarkan kebutuhan dalam menerapkan pembelajaran pada Web. Kondisi tersebut diasumsikan bahwa platform tersebut dapat diimplementasikan kedalam kelas lain yang jumlahnya lebih banyak dan bisa berjalan dengan normal. Penelitian dan pengembangan ini juga melibatkan seorang validator ahli desain pembelajaran. Validator ahli desain pembelejaran dibutuhkan untuk menilai apakah produk pengembangan yang telah dihasilkan layak untuk diterapkan ke dalam tahap berikutnya.

Jenis data pada penelitian dan pengembangan pembelajaran berbasis web dengan menggunakan model belajar generatif dikategorikan menjadi dua jenis data, yaitu data kuantitatif dan kualitatif. Data kuantitatif digunakan untuk menampilkan hasil penilaian data empiris berupa angka, sedangkan data kualitatif digunakan untuk menampilkan hasil yang berupa data verbal pada saat validasi. Teknik pengumpulan data dilakukan untuk menggali informasi atau masukan terkait pengembangan pembelajaran dengan menggunakan model belajar generatif. Teknik pengumpulan data yang digunakan pada penelitian dan pengembangan ini adalah wawancara, observasi, dan kuisioner. Data kualitatif diperoleh dari hasil karya dari responden penelitian dan pengembangan. Data tersebut kemudian dianalisa dengan cara membandingkan data tersebut dengan objek yang dinilai serta pengamatan di lapangan. Hasilnya akan dijadikan dasar untuk memberikan kesimpulan atas sebuah penilaian dari sebuah objek. Sementara itu, data kuantitatif diperoleh dari hasil penilaian empiris yang berupa angka-angka.

\section{HASIL}

Penelitian dan pengembangan kali ini menghasilkan produk pembelajaran berbasis web yang dikembangkan menggunakan teori belajar generatif. Terdapat tiga prosedur pembelajaran menggunakan model belajar generatif, yaitu menyeleksi, mengelola, dan mengintegrasikan. Kemudian sebagai penguatan aktivitas generatif diberikan penugasan dengan cara-cara generatif, yaitu learning by summarising dan learning by explaining (Fiorella \& Mayer, 2015). Berikut ini merupakan tampilan awal produk pengembangan. 


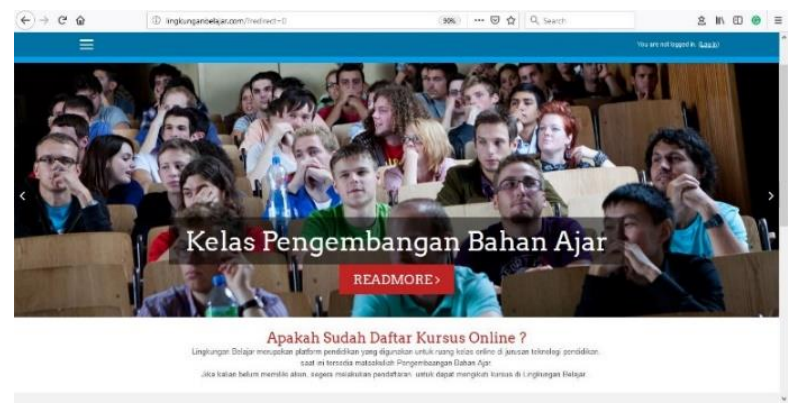

Gambar 2. Tampilan Awal Web Pembelajaran

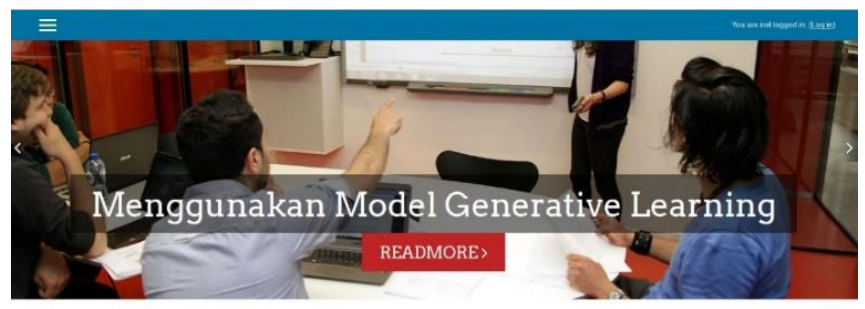

Apakah Sudah Daftar Kursus Online?

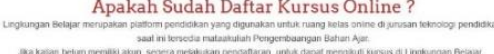

Gambar 3. Tampilan Sebelum Masuk Kursus Online

Gambar 2 dan 3 merupakan tampilan awal sebelum masuk pada halaman kursus, terdapat penjelasan tentang kursus yang akan diambil oleh mahasiswa yang akan memulai proses belajarnya. Selanjutnya, aktivitas yang dikerjakan oleh mahasiswa didalam web dijelaskan pada tabel 1 .

\section{Tabel 1. Rancangan Pembelajaran Berbasis Web Menggunakan Teori Belajar Generatif}

Sesi 1: Konsep Pengembangan Bahan Ajar

Tujuan Pembelajaran Umum:

Mahasiswa memiliki kemampuan menjelaskan konsep bahan ajar

Materi 1.1: Pengertian Bahan Ajar

Tujuan Pembelajaran:

Memiliki kemampuan menyebutkan berbagai macam bahan ajar

Materi 1.2: Peran dan Fungsi Bahan Ajar dalam Pembelajaran

Tujuan Pembelajaran:

Memiliki kemampuan menjelaskan peran dan fungsi bahan ajar dalam proses pembelajaran

Materi 1.3: Tujuan dan Manfaat Penyusunan Bahan Ajar

Tujuan Pembelajaran:

Memiliki kemampuan menjelaskan tujuan dan manfaat penyusunan bahan ajar dalam proses pembelajaran

\section{SESI I}

Aktivitas Pembelajaran:

1. Mahasiswa memilih salah satu materi-materi tentang konsep bahan ajar yang telah disediakan.

2. Mahasiswa membaca materi tentang konsep bahan ajar yang telah dipilih

3. Mahasiswa dapat mencari sumber-sumber yang relevan di internet untuk memperkaya pengetahuan.

1. Mahasiswa mennyebutkan lima contoh bahan ajar selain dari contoh bahan ajar yang terdapat di dalam materi

2. Mahasiswa membuat infografis menggunakan aplikasi online desain grafis (canva.com). Inforgrafis yang dibuat memuat informasi berikut ini:

a. Nama-nama lima contoh bahan ajar yang sudah disebutkan pada poin satu

b. Visual (icon/gambar) semirip mungkin dari nama-nama bahan ajar yang telah disebutkan

c. Berilah tahun awal kemunculan dari masing-masing bahan ajar yang telah disebutkan

d. Berilah penjelasan dari masing-masing bahan ajar

e. Letakan bahan ajar berdasarkan urutan tahun yang paling tua ke tahun paling muda. Urutan bisa dari atas ke bawah atau dari kanan ke kiri

f. Setiap bahan ajar yang disebutkan diberi penjelasan manfaat bagi pebelajar dalam proses pembelajaran

g. Desain infografis semenarik mungkin, gunakan kata-kata komunikatif, singkat, dan jelas serta gunakan simbol-simbol yang relevan. 
Setelah dilakukan uji coba produk, diperoleh hasil kerja mahasiswa berdasarkan aktivtias-aktivitas generatif, yaitu learning by sumarising dan learning by explaining. Kedua aktivitas tersebut merupakan penguat dalam menjalankan aktivitas belajar generatif pada web pembelajaran. Berikut ini merupakan hasil kerja mahasiswa berdasarkan aktivitas belajar generatif.

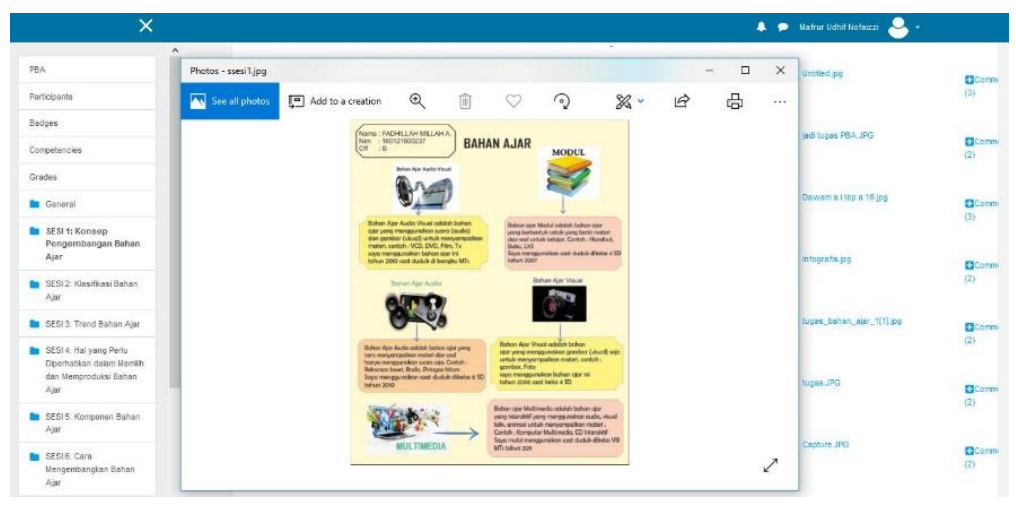

\section{Gambar 4. Hasil Kerja Mahasiswa Berdasarkan Cara Generatif Learning by Summarising}

Gambar 4 merupakan rangkuman yang ditampilkan dalam bentuk visual. Hasil kerja mahasiswa tersebut diperoleh dari hasil penugasan yang menggunakan cara belajar generatif Learning by Summarising.

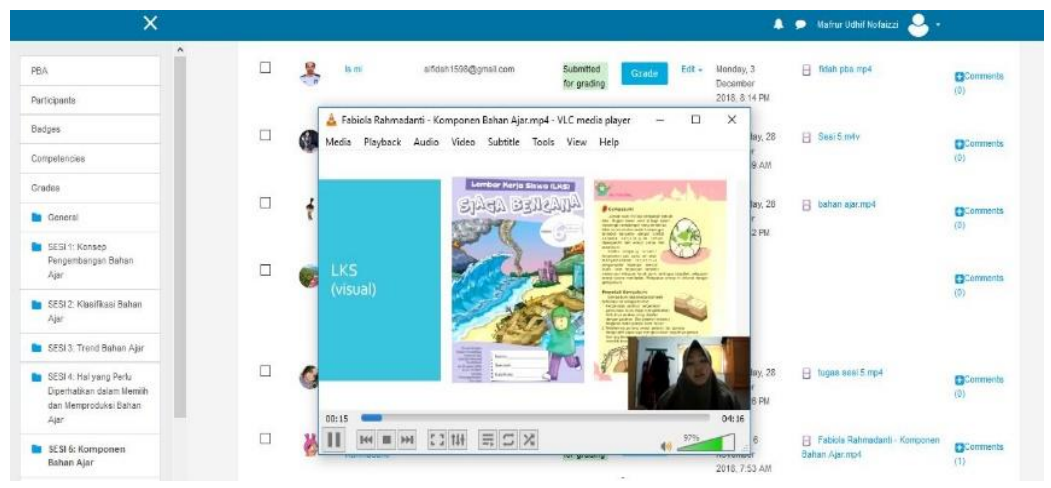

\section{Gambar 5. Hasil Kerja Mahasiswa Berdasarkan Cara Belajar Generatif Learning by Explaining}

Gambar 5 berisi tampilan produk mahasiswa sekaligus penjelasan melalui video. Hasil karya mahasiswa tersebut merupakan hasil dari penugasan yang menggunakan cara generatif learning by explaining. Berdasarkan hasil uji kemenarikan yang dilakukan pada 30 mahasiswa yang mengikuti proses pembelajaran. Aspek yang dinilai, meliputi kemenarikan terhadap web pembelajaran, kemenarikan terhadap aktivitas belajar yang dilakukan selama proses pembelajaran di dalam web, dan kemenarikan pada aktivitas penugasan yang dilakukan baik cara belajar learning by summarising maupun cara belajar learning by explaining diperoleh hasil 89,09\%. Hal ini menunjukkan bahwa mahasiswa tertarik dengan aktivitas belajar yang dilakukan pada pembelajaran berbasis web yang dikembangkan dengan menggunakan teori belajar generatif.

\section{PEMBAHASAN}

Hasil pengembangan yang telah diperbaiki berdasarkan uji validasi ahli desain pembelajaran serta respons dari mahasiswa menunjukkan bahwa hasil pengembangan pembelajaran berbasis web dengan menggunakan model belajar generatif dapat diimplementasikan kedalam proses pembelajaran. Berdasarkan hasil yang diperoleh melalui observasi pada saat proses pembelajaran, mahasiswa tidak mengalami kesulitan dalam mengikuti proses pembelajaran berbasis web yang menggunakan model belajar generatif. Berdasarkan hasil uji coba kemenarikan pebelajar dalam mengikuti proses pembelajaran diperoleh hasil $89,09 \%$. Hasil tersebut menunjukkan bahwa mahasiswa merasa nyaman ketika mengikuti proses pembelajaran. Kelebihan lain dari hasil pengembangan pembelajaran berbasis Web dengan menggunakan model belajar generatif adalah sebagai berikut.

Pertama, model pembelajaran generatif pada lingkungan belajar daring memuat aktivitas-aktivitas belajar yang melibatkan pebelajar secara aktif dalam proses pembelajaran. Hal ini sejalan dengan pernyataan Osborne \& Wittrock, (1985) yang menyatakan bahwa model belajar generatif dapat melibatkan pebelajar secara aktif mulai dari proses memilih sumber belajar hingga proses pengintegrasian informasi ke dalam struktur pengetahuan baru. Penggunaan model belajar generatif memberikan dampak yang signifikan terhadap kemampuan pebelajar tidak hanya kemampuan menghafal, tetapi juga 
kemampuan kognitif secara keseluruhan (Reid \& Morrison, 2017). Hal ini menunjukkan bahwa penggunaan model belajar generatif dapat meningkatkan keaktifan mahasiswa dalam proses belajarnya.

Kedua, penugasan yang diberikan kepada mahasiswa memberikan pengalaman baru dalam usahanya untuk belajar, sebagai contoh pada tugas sesi pertama, mahasiswa membuat infografis yang berisi rangkuman materi pembelajaran. Elaborasi personal lebih berkesan bagi pebelajar karena mendapatkan pengalaman dan pengetahuan dasar secara mandiri (King, 1992). Proses integrasi antara keterampilan mengolah grafis dengan kemampuan memahami materi menjadi kekuatan dalam menyimpan pengetahuan ke dalam memori jangka panjang (Fiorella \& Mayer, 2016).

Ketiga, penugasan yang diberikan pada setiap sesi memotivasi mahasiswa untuk belajar tidak hanya tentang konsep yang dibahas, tetapi juga belajar tentang konsep-konsep di luar topik pembahasan termasuk juga kemampuan prasyarat yang lain. Atribusi dan kemenarikan merupakan faktor utama dalam motivasi (Wittrock, 1992). Apabila kedua aspek tersebut dapat dikelola, maka pebelajar akan termotivasi untuk belajar. Peningkatan motivasi belajar tersebut sejalan dengan penelitian yang menyatakan bahwa model belajar generatif berimplikasi pada meningkatnya motivasi belajar pebelajar (Anderman, 2010).

\section{SIMPULAN}

Pengembangan pembelajaran berbasis web menggunakan model belajar generatif merupakan sebuah inovasi baru dalam pembelajaran abad ke-21. Selain dapat meningkatkan kemampuan kognitif pebelajar, penerapan model belajar generatif juga dapat meningkatkan kemampuan intrapersonal maupun interpersonal. Hal ini dapat dilihat dari penugasan yang diberikan membutuhkan kemampuan teknis tambahan seperti desain grafis dan editing video.

Saran untuk pengembangan berikutnya adalah dapat mengkaji dampak secara spesifik dari masing-masing peugasan terhadap hasil belajar mahasiswa. Hal ini dikarenakan penelitian ini hanya terbatas pada prosedur pengembangan pembelajaran berbasis web dengan menggunakan cara generatif, sedangkan hasil kerja mahasiswa dapat dinilai secara bagus, namun belum diteliti lebih jauh terkait dampak yang lebih spesifik.

\section{DAFTAR RUJUKAN}

Anderman, E. M. (2010). Reflections on Wittrock's Generative Model of Learning: A Motivation Perspective. Educational Psychologist, 45(1), 55-60. https://doi.org/10.1080/00461520903433620

Beth, A. D., Jordan, M. E., Schallert, D. L., Reed, J. L. H., \& Kim, M. (2015). Responsibility and Generativity in Online Learning Communities. Interactive Learning Environments, 23(4), 471-484. https://doi.org/10.1080/10494820.2013.788035

Davidson-Shivers, G. V., Rasmussen, K. L., \& Lowenthal, P. R. (2018). Web-Based Learning (second). Cham: Springer International Publishing. https://doi.org/10.1007/978-3-319-67840-5

Fiorella, L., \& Mayer, R. E. (2015). Learning as a Generative Activity: Eight Learning Strategies That Promote Understanding. Cambridge: Cambridge University Press. https://doi.org/10.1017/CBO9781107415324.004

Fiorella, L., \& Mayer, R. E. (2016). Eight Ways to Promote Generative Learning. Educational Psychology Review, 28(4), 717741. https://doi.org/10.1007/s10648-015-9348-9

Grabowski, B. L. (2004). Generative Learning Contributions to the Design of Instruction and Learning. Handbook of Research on Educational Communications and Technology, (January 2004), 719-743.

J. Reid, A., \& R. Morrison, G. (2017). Generative Learning Strategy Use and Self-Regulatory Prompting in Digital Text. Journal of Information Technology Education: Research, 13, 049-072. https://doi.org/10.28945/1948

Kalyuga, S. (2009). Cognitive Load Factors in Instructional Design for Advanced Learnenrs. Annals of Vascular Surgery (Vol. 19). Nova Science. https://doi.org/10.1007/s10016-004-0163-X

King, A. (1992). Facilitating Elaborative Learning Through Guided Student-Generated Questioning. Educational Psychologist, 27(1), 111-126. https://doi.org/10.1207/s15326985ep2701_8

Lee, H. W., Lim, K. Y., \& Grabowski, B. L. (2008). Generative Learning: Principles and Implications for Making Meaning. In J. M. Spector, M. D. Merrill, J. Van Merrienboer, \& M. P. Driscoll (Eds.), Handbook of Research on Educational Communications and Technology (pp. 112-123). https://doi.org/10.1017/CBO9781107415324.004

Mayer, R. E. (2010). Merlin C. Wittrock's Enduring Contributions to the Science of Learning. Educational Psychologist, 45(1), 46-50. https://doi.org/10.1080/00461520903433547

O’Neal, L. J., Gibson, P., \& Cotten, S. R. (2017). Elementary School Teachers' Beliefs about the Role of Technology in $21^{\text {st- }}$ Century Teaching and Learning. Computers in the Schools, O(0), 1-15. https://doi.org/10.1080/07380569.2017.1347443

Osborne, R., \& Wittrock, M. (1985). The Generative Learning Model and its Implications for Science Education. Studies in Science Education (Vol. 12). https://doi.org/10.1080/03057268508559923

Pellegrino, J. W., \& Hilton, M. L. (2013). Education for Life and Work: Developing Transferable Knowledge and Skills in the $21^{\text {st }}$ Century. Education for Life and Work: Developing Transferable Knowledge and Skills in the $21^{\text {st }}$ Century. https://doi.org/10.17226/13398

Richey, R. C., Klein, J. D., \& Tracey, M. W. (2011). The Instructional Design Knowledge Base: Theory, Research, and Practice. Journal of Chemical Information and Modeling (Vol. 53). https://doi.org/10.1017/CBO9781107415324.004 
Rothwell, W. J., Benscoter, G. M. B., King, M., \& King, S. B. (2015). Mastering the Instructional Design Process. Mastering The Instructional Design Process. https://doi.org/10.1002/9781119176589

Smith, P. L., \& Ragan, T. J. (2005). Instructional design. Performance + Instruction (3rd ed.). John Wiley \& Sons.

Wilhelm-Chapin, M. K., \& Koszalka, T. A. (2016). Generative Learning Theory and its Application to Learning Resources. Ridlr, (figure 2), 1-8.

Wittrock, M. C. (1974). Learning as a Generative Process 1. Educational Psychologist, 11(2), 87-95. https://doi.org/10.1080/00461527409529129

Wittrock, M. C. (1992). Generative Learning Processes of the Brain. Educational Psychologist, 27(4), 531-541. https://doi.org/10.1207/s15326985ep2704_8 